\title{
The Thin Blue Line of Theodicy: Flannery O'Connor, Teilhard de Chardin, and Competitions between Good/Good and Evil/Evil
}

\author{
Sue Whatley \\ English, Stephen F. Austin University, Nacogdoches, TX 75962-3007, USA; swhatley@sfasu.edu; \\ Tel.: +1-936-468-2031
}

Received: 17 January 2018; Accepted: 23 March 2018; Published: 24 April 2018

\begin{abstract}
This essay explores the concept of theodicy in Flannery O'Connor's works of fiction. O'Connor's fiction complicates the subjects of good and evil, moving the reader through what seem to be competitions not only between good and evil, but also between actions of good and actions of evil. Characters align themselves with one force, then another, in a constantly fluctuating system, and there is no traditional pattern of Christian warfare that we would expect orthodox Catholic writing to produce. Sometimes, evil brings about the resolution of the narratives, and sometimes actions of good fail to redeem. It is only through the theology of Pierre Teilhard de Chardin that we may have a full understanding of $\mathrm{O}^{\prime}$ Connor's Christian vision. For O'Connor, Teilhard's system of a dynamic eternity, which is in the process of unification, gives a greater understanding of our human reality, as it is a world where evil is used at the service of the Divine. It serves her fictional goal as well, as it allows her to rescue violence and evil from its power for despair.
\end{abstract}

Keywords: Flannery O'Connor; Teilhard de Chardin; good and evil; theodicy; Christian vision

\begin{abstract}
"What has given the South her identity are those beliefs and qualities which she absorbed from Scriptures and from her own history of defeat and violation: a distrust of the abstract, a sense of human dependence on the grace of God, and a knowledge that evil is not simply a problem to be solved but a mystery to be endured". (O'Connor 2009)
\end{abstract}

In the Augustinian sense-that "evil" is the absence of good-we can accept that God is not a creator of evil. The most persistent problem of good and evil—especially that of a domestic sort-lies not in the question of whether good and evil exist, or even in the question of how to resolve the Divine Paradox, but in the actual naming of what is good, and what is evil. The adage "beauty is in the eye of the beholder" might ring true for "good" as well, for every generation brings forth recognition, reversal and intention in the process of identifying destructive forces and ultimate evil. Author Flannery O'Connor, an orthodox Catholic, bore witness to the phenomena, and she on more than one occasion indicated that through God's allowance of the existence of "an evil," one may become more than his/her original conception. We are "blessed in our deprivations" (The Habit of Being, pp. 168-69). It is with some hesitation that I conflate the terms "deprivation" and "evil," though I will maintain that, in much of $\mathrm{O}^{\prime}$ Connor's fiction, the two are-if not indistinguishable-at least easily associated. Some of these deprivations are man-made, while others exist as random natural phenomena. Regardless of the source, a multitude of deprivations and evil actions unify O'Connor's narratives; they vie for narrative control, and they lead to the only moments in the fiction we might label as "resolution." Oddly enough, the actions which we might call "good"—or at least those which seem to be moving the characters toward it-also seem to be competing with each other in much the same manner. 
That critics find O'Connor's notions of good and evil confusing is an understatement. Today, she is noted as one of the greatest spiritual writers of the Twentieth Century, and the literary quality of her work has allowed a kind of bridge between literary purists and seekers of theological fiction. Even so, many of her readers fail to discern any Christian design in her work, and some even celebrate the absence of that traditional structure. Others, however, armed with O'Connor's own theological explanations come to the fiction with a sense of expectation, and despite $\mathrm{O}^{\prime}$ Connor's statements about using exaggeration in order to have the "blind see" and the "deaf hear," the actual identification of good and evil has proven to be a rich source of debate in the critical work that has ensued. John Hawkes, a fellow novelist and early critic of O'Connor's work, claimed that "O'Connor uses the voice of the devil to destroy man's belief that he [himself] is rational" (Gentry 1986, p. 143). Others concur that the narrator is a sadistic or devilish figure (Clair Katz Kahane and Josephine Hendin, among others) and O'Connor herself did not disagree (Gentry 1986, p. 143). How, then, does a Christian novelist avoid inferior, didactic writing while attempting to make clear a spiritual path? O'Connor's rich fictional world allows entrance to an extension of reality-what she called a "reality of distance" - and it underscores the difficulty of assigning simple labels to complex actions of good and evil.

In all but the rarest works of Divine Comedy, the battle between good and evil is central to the impetus of each character's actions, and that same current determines the eventual unity of the story. In some sense, $\mathrm{O}^{\prime} \mathrm{C}$ onnor's fiction is no different. Readers are likely aware of the actions and forces which seem to push toward outcomes that we might consider good or evil. The challenge lies in identifying where those forces of good and evil manifest themselves. If evil brings forth suffering, and deprivation is one cause that leads to suffering, then the eradication of the cause of that deprivation must be the goal of Christian and humanist. It is difficult to conceive of a deprivation as anything other than "not good," but deprivations fall into a hierarchy. Deprived of food, man may turn to theft in order to survive or bring about the survival of his/her children. This state of existence draws sympathy from most humans, as they recognize human suffering. A mother might even be compelled to personal depravity in order to provide shelter for her children. Modern story tellers explore the dilemma ad nauseum, especially in film and television; stories that push the boundaries of good and evil flood every venue- - the drug addict mother who sells drugs, not to score another fix but to hire the best (worst?) attorney whose connections with the judge may keep her from losing her children. The crime syndicate leader's tortured childhood at the hands of his father has led him to become the toughest person in his borough. The hierarchy grows, and where the line is to be drawn between frailty and maliciousness is indeed a problem of philosophical proportions. In our attempt to discern an individual's motivation, we might possibly find ourselves understanding and "forgiving" an action of depraved indifference, though many might certainly categorize it as evil. Inversely, we might forego our ability to sympathize with the actions of a character whose mistaken judgment leads to the deaths of hundreds of people, and to his own eternal misery and guilt.

The concept of good and evil, then, is always subject to parameters, to those examples that are "surely good" and "surely evil." From there, we move to judge or at least relegate actions and people to the category of good and bad, edifying or evil. When characters are created then, on that very fine line, and the readers' or critics' judgments do indeed co-create the script, they are forced to decide whose actions then are those to follow, and whose actions clearly depart from the new sensibility the reader must have after engaging the text.

My early arguments against popular feminist dismissal of O'Connor's contributions sought to redeem her maternal characters from the general perception that they are, at best, socially broken and impotent, or, at worst, catalysts of agony and torture for their children. Instead of seeing them as agents of human misery, evil it might be labeled, I have urged that we see them as "equally flawed"-in a violent world, where humanism and Divine Grace are hidden from view. In addition, while I still maintain my claim that $\mathrm{O}^{\prime}$ Connor's matriarchal characters are no more destructive/evil than their children or peers in her fiction, it may be time to consider just how difficult the dichotomy, when any one character is charged with "good behavior" and another with "bad behavior." In engaging fiction, 
as with engaging life, when we seek to separate God from man, good from evil, the task becomes more complex with every consideration. As our compassion grows, it is easy enough to conclude that all characters, all people, are flawed; the result of this kind of reasoning is human understanding. We come to understand human frailty and identify our own negative actions as such. The danger, however, is that we may become complacent in our estimation of our own flaws, satisfied to some extent that we are no longer facing a "greater judgment" than others, that we are just as likely to be redeemed as they. Our own desire to rid ourselves of actions that lead to others' misery is often mitigated by our growing sense of our participation in human frailty.

It would be easy to fall into this trap when reading O'Connor's work, given the sheer amount of violence depicted. Make no mistake, $\mathrm{O}^{\prime}$ Connor's fiction is not a defense of human frailty, nor does she invite the kind of sentiment that would allow for it. She is not a "humanist" in the sense of defending man's frailty and warns against the mindset of the "average Catholic reader":

By separating nature and grace as much as possible, he [the average Catholic] has reduced his conception of the supernatural ... He forgets that sentimentality is excess, a distortion of sentiment usually in the direction of an overemphasis on innocence, and that innocence, whenever it is overemphasized in the ordinary human condition tends by some natural law to become its opposite. (Mystery and Manners, hereafter MM: O'Connor 1962, pp. 147-48)

With O'Connor, we are not merely viewing a simplistic system of identifying good and evil, but, instead, witnessing competitions between "good" actions. Likewise, we are viewing competing actions of evil. O'Connor's vision seems to insist that whether through our own evil, fallibility, or good, we are somehow brought face to face with God, and thereby prove his existence on a personal level. God, then, uses the existence of evil, just as he uses the existence of good, in order to bring about spiritual awakening. If the struggle between good and evil characterizes the literature of several thousands of years, then $\mathrm{O}^{\prime} \mathrm{C}$ onnor pierces the simplicity of those categories by depicting the struggle between layers of "good" and the additional struggle between layers of "evils." O'Connor's stories clearly reveal an evolutionary process in the competitions between the forces of good, evil, and good/evil.

In her most anthologized story, "A Good Man is Hard to Find," O'Connor's serial killer, referred to as "the Misfit," leads the Grandmother to a place of "goodness," a place where she meets God for the first time. Oddly, he does so by the use of violence, and the horrendous atrocity of killing her family, and, while violence is usually associated with evil and it would be difficult to label the mass murder of a family (including young children and a baby) as anything else, in this story, as with many of her works, violence becomes "strangely capable of returning [her] characters to reality and preparing them to accept their moment of grace" ("On Her Own Work," MM, p. 112). The grandmother's true self is questionable as well, though she carries herself in a manner that emanates kindness and respect. She lies when it is convenient, and she manipulates her son. These actions, coupled with her inability to think before she speaks, lead to her family's deaths and her own. In a hierarchy of sin/evil, readers are hard pressed to see a discernible difference between the grandmother and the Misfit. The simultaneous actions of evil on the part of the Grandmother and the Misfit lead them both to a place of discovery, what Teilhard de Chardin calls the "omega point" - where a person meets God and must decide whether to accept Grace or not. The grandmother's declared recognition of the Misfit as a serial killer, leads to her family's ultimate demise. When she attempts to rectify her mistake and save her own life by calling him "good," the Misfit thanks the grandmother. Later, when she twice more repeats the claim, he first claims that he is not "good," then later reverses again: "I never was a bad boy that I remember of...but somewhere's along the line, I done something wrong'"' (Flannery O'Connor: The Complete Stories, hereafter CS: O'Connor 1987, p. 130). At a certain point, the Grandmother recognizes the benefit of pleading the cause of Christian redemption and asks the Misfit to pray; the Misfit places his cards on the table: if he had been "there"-with Jesus as he performed the miracle of raising someone from death—he "would of known and I wouldn't be like I am now'" (CS, p. 132). The Misfit believes the argument is over, but in the one moment the Grandmother opens herself to true human compassion, 
calling him "'one of my babies,'” (CS, p. 132) his notions of pleasure (to go about doing meanness) are shattered. His final line assures the reader that neither goodness nor evil bring any kind of victory or pleasure. He has been brought to a moment of confrontation, and he is "there"-face to face with God, in the form of a stubborn, selfish old woman, whose contribution of "good" is in the fraction of a second before death: "'Shut up, Bobby Lee...It's no real pleasure in life'" (CS, p. 133).

It appears the questionable nature of labeling "good" and "evil" was a concern for O'Connor throughout most of her writing life. In one of her early stories, "The Turkey," a young boy "tries on" his habit of evil, just as he tries on his habits of "good." Ruller, lost in his rich fantasy world, is pulled into a spiritual reality when he discovers an injured turkey, one which he might be able to capture and take home. He envisions his parents delighted as he enters the front door, "screaming, 'Look at Ruller with that wild turkey! Ruller! Where did you get that wild turkey?'" (CS, p. 43). Ruller's belief that his parents "might like to have him catch them one" reveals his position in the family dynamics (CS, p. 43): his older brother Hane has apparently been acting out, defying not only family expectations but societal ones as well. The expectation that Hane may end up in the "penitentiary" has caused so much disharmony, that Ruller's initial desire is to please his parents.

Ruller's altruism is short-lived, however, and soon we see that the goal of pleasing others has a self-interested flip-side. He wants to please his parents because he is in competition with his brother. As the chase of the turkey continues, Ruller surmises that his parents will begin to discuss him, instead of Hane, in their late night conversations. Soon Ruller has torn his clothes and begins to worry about the trouble he might get in, and the turkey begins to become a necessity, rather than a boon. However, the turkey seems to evade him, and, when it appears he will not be caught, Ruller thinks that "somebody had "played a dirty trick on him" (CS, p. 45). The disappointment and apprehension he experiences morphs his intention for "good" into defiance and blasphemy. Ruller begins vocalizing slang words, progressing to curses which incorporate the name of God, and he is delighted with himself, laughing and giggling with every subsequent vulgarity. He mentally plans his own spiritual demise, inventing elaborate scenarios about lies and thefts he could engage. Ruller is not a child who mimics others, lacking a sense of good and evil. He knows he shouldn't be angry with God for "sticking things in your face and making you chase them all afternoon for nothing... But that was the way he felt" (CS, p. 48).

But the story does not end with Ruller's slipping toward evil. The turkey dies of exhaustion, a sign that Ruller sees it as a sign that "God had stopped him before it was too late" (CS, p. 49). In addition, Ruller is appreciative; he contemplates what God wants him to do, the "good" actions that can transform society-bequeathing money to the town poor, and "found[ing] a place for boys to stay who were going bad" (CS, p. 51) or "a home for tenants children" (CS, p. 51). Ruller's estimation of himself grows exponentially, as he prides himself in his resistance to the temptation of evil. He feels so "chosen" by the Divine that he asks God send him a "beggar" so that he may donate the only money he has on him-a dime. Both the reader who is looking for a story depicting the conquest of good over evil and Ruller himself are thwarted, as the story has yet another reversal. The country boys who seem to be the inspiration of Ruller's magnimanity follow and soon overtake Ruller and the turkey he carries, stealing it before Ruller has an opportunity to even realize what is happening. There the story ends. The reader is left to assume that Ruller's pride will be checked, that his eventual understanding of God will grow deeper than the simple notions he has developed while chasing and capturing the turkey. Neither Ruller's good behaviors nor his evil ones bring the ultimate spiritual victory-but instead the spiritual world is illuminated by its competitions between "good" actions and intentions, and the similar competitions between evil actions.

All of these competitions provide Ruller's experience of revelation and growth. He has no model of good to follow, and it is only in the experience of both that he finds the path of spiritual discovery. In addition, we as readers have just as much difficulty locating the forces of good and evil. Is it God who provides the turkey and evil which snatches it? Or evil which provides and God who takes away? O'Connor gives closure to the story and the murky business of defining "evil" and "good" 
with her final line of the story: Ruller is "certain that Something Awful was tearing behind him with its arms rigid and its fingers ready to clutch" (CS, p. 53). If this spirit is, indeed, the spirit of God, working to move Ruller on a spiritual path, why then does the narrator label it "Something Awful"? The play on terms "awful" and "awe-ful" further underscores the difficulty of identifying the forces of good and evil. Our question about the force that determines Ruller's outcome is yet to be answered. Only Ruller's future, his actions and decisions that spring from this encounter with the turkey, will serve to prove whether the force was a good or evil one.

In some of $\mathrm{O}^{\prime}$ Connor's stories, it is difficult to see any victory other than one evil over another. The stories "A View of the Woods" and "The Comforts of Home" both offer protagonists who compel little sympathy, and there seems to be no moment of grace or redemption. Critic A. R Coulthard considers "A View of the Woods" one of O'Connor's least effective stories, and notes that O'Connor herself was frustrated in her work on the piece. Coulthard calls the story O'Connor's "worst piece of fiction." She goes on to address the failure of the author to offer characterization that elicits sympathy or respect (Coulthard 1987). Mr. Fortune and his son-in-law Mr. Pitts vie for control of his granddaughter, Mary. When she chooses neither her grandfather nor her father for guidance or resolution, even the sympathy that would normally be afforded a child disappears. Her murder of her grandfather further cements the verdict: none of the characters clearly approach Grace within the confines of the story. In "The Comforts of Home," Thomas's mother seems sympathetic, compassionate, but falls prey to Star Drake's (Sarah Ham) manipulations. What begins as an effort on his mother's part to help the "unfortunate" ends in Thomas's mother's accidental death, and his arrest, based on Star's arrangement of fake evidence and lies. Thomas's inability to allow his mother's more compassionate nature to rule him sets him up for the accidental violence which takes his mother's life. While she is alive, Thomas is pulled between his mother's kind nature and the memory of his powerful father, who has died years before. When his mother dies, he is left with only his father's physical power, explosiveness and penchant for violent action.

In other stories, the competitions between actions of good and actions of evil seem more evident. "The Displaced Person" offers a litany of good and evil traits within all characters, but none seem to gain ultimate control over the characters' actions. Mr. Shortley's attempt to take advantage of any female in charge, smoke in the dairy, and tout his white privilege over the black workers on the farm undermine any sense of goodness he might claim as a defense for the injustice he receives in being replaced by new workers on the farm. Even Mrs. Shortley's "extreme" and visionary faith, a kind of faith that $\mathrm{O}^{\prime}$ Connor seems to approve of, is centered in the notions of social hierarchy and racism. Mrs. McIntyre's story begins with her being urged towards compassion for the displaced family, and her action of hiring Mr. Guizac and providing for his family seems a movement in the direction of "good." However, Mrs. McIntyre's intentions for bringing in the displaced family are no purer than Mr. Shortley's desire for undeserved advancement. She intends to modernize and use to her advantage the desperation of a family who is at the mercy of strangers. During subsequent visits with the priest, she seems to move further away from theological enlightenment or human compassion, and she rages against the priest's guidance: “'As far as I'm concerned, Christ was just another DP [displaced person]"' (CS, p. 229). She pits Mr. Guizac, Mr. Shortley, and the two black farm hands, Astor and Sulk, against each other, offering up her financial worries and the threat of dismissal to push competition and more productivity. And when Mr. Guizac arranges the marriage of his "white" cousin to Sulk, her adherence to the racial status quo of the South leads her to not only to threaten to put the Guizacs off the farm, but also to collude with Mr. Shortley and Astor in inaction when the tractor threatens to run over Mr. Guizac. The actions of good and evil are constantly mutating in O'Connor's stories, and none seems to produce clear, discernible power over characters who would seem to be moving on the trajectory toward Grace.

It is with $\mathrm{O}^{\prime}$ Connor's connections to Teilhard de Chardin that we may see her Christian narrative intent, and understand how competitions between good actions and competitions between evil ones all lead to Divine order and unity. O'Connor takes her cue from Teilhard and his three basic laws 
governing the structure of reality. Teilhard's dilemma as a scientist is that he wanted to investigate those matters which the Church saw as threatening — evolutionary theory included-and his theories would of course have to account for ways to rename or reclaim science as divinely inspired —or at least contained. Teilhard's three basic laws - the law of conservation of energy, the law of entropy, and the law of complexity seek to explain the dynamic system in which the natural world and the spiritual world move simultaneously toward clear unification. The law of conservation of energy and the law of entropy suppose the finite system of creation and the way in which systems of nature maintain balance and flow. The law of complexity stems from the first two laws but pushes understanding of the natural world to account for man's place in the system. Teilhard claims that all things bear some degree of consciousness, but that man by design holds "the highest degree of consciousness." Within these concepts, all matter has the potential and an obligation to become more complex; through this "complexification," existence is given the power to change, and the unified world becomes greater than the sum of its parts (McCarty 1976, pp. 40-42).

In their book, Teilhard's Seven Stages of Suffering: A Spiritual Path for Transformation Louis Savery and Patricia Berne examine Teilhard's notions about how God transforms evil. Teilhard offered guiding principles: God is capable of making good come out of evil; everything is capable of being transformed into good; the transformation may not be completed instantly; spiritual practice may be capable of redirecting unwanted feeling and restoring energy; those practices would include a dialogue with unwelcome feelings, forgiveness, spiritual will making, and prayers of thankfulness during times of suffering as well as prayers to the Holy Spirit for patience (Savery and Berne 2015, "Stage 4: Patience").

Teilhard's understanding of human frailty, deprivation, and evil is that all these will be made to serve Divine Good. We would rightly call this evolutionary theodicy, as time and revelation together will ultimately reveal the Divine use of those matters. Though she does not use the terms evolutionary theodicy or Divine convergence, $\mathrm{O}^{\prime}$ Connor understood the radical nature of the concept and its ability to encompass evil and direct it toward good. O'Connor's notions of the dramatic movement from evil toward good can be seen in her explanation of her character the Misfit from "A Good Man is Hard to Find": "I don't want to equate the Misfit with the devil. I prefer to think that, however unlikely this may seem, the old lady's gesture, like a mustard seed, will grow to be a great crow-filled tree in the Misfit's heart, and will be enough of a pain to him there to turn him into the prophet he was meant to become" (MM, pp. 112-13). She also understood the concepts surrounding convergence as an answer to the failures of the Church to satisfactorily explain and alleviate human suffering. She once replied to her friend Betty Hester that the church could not be explained simply by Freudian theories or Carl Jung's meta-theory of archetype: "The things that you think she [the true church, not "vapid" Catholicism] will be added to will be added to her [emphasis mine]" (The Habit of Being, hereafter, HB: O'Connor 1979, p. 99).

In a letter to friend Rosalyn Barnes, O'Connor indicated that Teilhard's laws governed not only the title but the substance of her story and beyond: "I have also written and sold to New World Writing a story called "Everything That Rises Must Converge", which is a physical proposition that I found in Pere Teilhard, and am applying to a certain situation in the Southern states and indeed in all the world" (HB, p. 438). It is also within this system that we find $\mathrm{O}^{\prime}$ Connor's inability (perhaps refusal) to make absolute the elements of evil and the elements of good. In her story, "Everything that Rises Must Converge" the refusal to delineate between good and evil is even more apparent. If we follow a traditional engagement of the story, sorting out which character is protagonist and which is antagonist, we may find ourselves, as many of my students, offering Julian up as a kind of protagonist: he is angry at his mother, and he carries a righteous indignation over her belief that white people are "superior." He recognizes the flawed social order, and appears to push toward equity for black citizens, who clearly can afford the same clothing and practices as their white counterparts.

However, this reading would be erroneous, and it would certainly not bring us any closer to an understanding of God, or an awareness of his existence in the world as the purveyor of good, because to see the story that way is to invite self-satisfaction. Julian is the target of the epiphany, and before he 
gets there, $\mathrm{O}^{\prime}$ Connor takes us through his failures: he maintains a lack of affection and respect for a woman who has sacrificed and supported him, even after the time when most parents would expect self-sufficiency. Julian, ironically, practices a kind of hierarchy of person, much deeper and much more subtle than his mother. He only wants to sit with "educated" blacks, and not in an effort to share intellectual experience. He simply wants to irk his mother. When his plan to humiliate her over the black doppelgänger fails, he cannot be satisfied with his mother's self-correction. Instead, he sets out to "show her." He belittles her, he talks to her as an infant, and reveals his willingness to conscript people of another race and objectify them in order to teach his mother a lesson: he contemplates his mother "desperately ill and his being able to secure only a negro doctor" (CS, p. 414). He ultimately reveals his own sordid bias and racial distortion when he chooses to sit with "some of the better types" of black people on the bus (CS, p. 414) and mentally laments his own loss of social privilege: "He thought bitterly of the house that had been lost for him" (CS, p. 419)—a house which clearly had been bought by the blood of slaves. He even contemplates marrying a black woman so he can rub his mother's face in the action. Though the story may have begun in the good of Julian's social enlightenment, it surely shifts as it unfolds, and it ends with Julian's corrupt nature.

If we see his initial action-the attempt to change his mother's racial bias-as "good," we must soon recognize his "good" actions are, nevertheless, in competition with his mother's good efforts-her support of him as a struggling young writer, her ability to laugh at herself over the irony of wearing the same hat as a black woman, and her genuine affection for certain black people in her life-her childhood nurse, Caroline, and the boy on the bus, Carver. Even so, it is not until his mother succumbs to her health failures, with a stroke, that Julian has any clue about his own competing evil. "The tide of darkness seemed to sweep him to back to her [his mother], postponing from moment to moment his entry into the world of guilt and sorrow" (CS, p. 420). It is neither his "goodness" nor his mother's, her "evil" nor his own which account for the eventual shift, but the complex interplay of competing evil and competing good that allow for God to bring Julian to a place of human rectification. In O'Connor's terms, the system that allows the existence of the negotiation of these forces is a Divine one.

No story holds greater ability to reveal the good/good evil/evil competition than the story "Revelation." A common reading of the story might go something like this: Ruby Turpin, a biased bigot, is accosted in a doctor's office one day, while stewing in her self-satisfaction. An emotionally-unstable, pock-marked, overweight young woman, who acts as an avenging angel, throws a book (Human Development) at Ruby, knocking her out of her smug complacency. As a result of her experience, Ruby is propelled toward an eventual revelation of her own fallen nature and the prevenient Grace which equalizes all human life.

O'Connor herself validated her friend Maryat Lee's claim that she made "Mary Grace" so ugly because she "loved her so much" (HB, p. 578). If we begin our understanding of the story with O'Connor's validation of Mary Grace, and read it as a competition between good and evil, then we must identify evil in the character of Ruby Turpin who is centered in the smugness and self-satisfaction. However, O'Connor has taken great pains to show us not only the battle and the events which lead up to it, but also the eventual vision of the source of that evil. Ruby enters the waiting room of the doctor's office, quickly pointing out a seat for her husband, Claud, whose leg has been injured by an accident involving one of their livestock. She is considerate enough to seat him, even though he makes a begrudging effort to give Ruby his seat. Claud at least attempts to show respect; others in the waiting room do not. There are at least six other people, including a young child, who do not offer or even acknowledge Ruby's need for a seat. If Ruby is, indeed, the worst example of humanity, how are we to categorize the others held up for comparison?

No one in the waiting room seems to offer anything other than judgment, and Mary Grace is not set apart from the others. She, too, has her own agenda: "The girl raised her head and directed her scowl at Mrs. Turpin, as if she did not like her looks. She appeared annoyed that anyone should speak while she tried to read" (CS, p. 490). Ruby's compassion for Mary Grace's physical attributes actually does seem to stem from her awareness of how harsh society can be to those who do not 
meet certain standards. Her response to Mary Grace is not one of revulsion, but instead, one which recognizes Mary Grace's plight. In fact, it is Ruby's preparation for the ultimate encounter that forces us to question Ruby's function in the good/evil world. Ruby may contemplate "who she would have chosen to be if she couldn't have been herself," but she moves away from that self-centeredness, and on to "naming the classes of people" (CS, p. 491). These are not classes that Ruby has created, but merely classes she recognizes, and the more deeply she considers these groups, the "complexity of it" begins to "bear in on her" (CS, p. 491). Ruby does not place herself at the top of the hierarchy; she recognizes the system that relegates humans to various positions of power, and she also recognizes how flawed the system is that cannot account for categories of nuance-well-mannered people of all races, people of stature without money, and so on.

While Ruby does indeed seem to be capable of thinking of the falseness of societal hierarchies, she is also a participant in the system, one which affords her power, however temporary, and one that demands her ability to keep that power if she is flexible within that system. She recognizes the changing social order and that she must accommodate the black people who work for her and Claud. While the "white-trash" woman debases Ruby for her negotiation of the cultural system (raising hogs instead of cotton, greeting the hired help) Ruby remains openly polite (CS, p. 494). However, her divine catalyst-Mary Grace-stews in her private fury at a woman whose flaws, or evil, we might say—barely seem intentional.

If Mary Grace is an avenging angel, one would expect her to maintain some redeemable qualities-something that might model "good" as well as point out "evil." However, all of Mary Grace's actions are more judgmental, more violent than Ruby's. Once Ruby and Mary Grace's mother agree that accepting changes in societal structures is necessary, Ruby begins to notice that Mary Grace's "peculiar eyes were still on her" (CS, p. 494). The hierarchy continues to unfold; admirably, Mary Grace's mother and Ruby both deflect the "white-trash" woman's declaration: "They ought to send all them niggers back to Africa...That's where they come from in the first place" (p. 495). While Ruby and Mary Grace's mother reveal their own fallen humanity in their responses, they do at least practice civility and flexibility; however, Mary Grace is as entrenched in her response to their bigotry, as the "white trash" woman is in her own. She and Mary Grace demonstrate no potential for change, and it is clear that Mary Grace has chosen Ruby's flaws as the target for her own personal dissatisfaction; thus, Mary Grace's own sense of humanity deteriorates before our eyes:

As she said it, the raw-complexioned girl snapped her teeth together. Her lower lip turned downwards and inside out, revealing the pale pink inside of her mouth. After a second it rolled back up. It was the ugliest face Mrs. Turpin had ever seen anyone make and was looking at her as if she had known and disliked her all her life-all of Mrs. Turpin's life, it seemed too, not just all the girl's life. (CS, p. 495)

Mary Grace is rude to not only Ruby, but to her mother as well. As her mother's anger grows and she enlists the help of others in the waiting room to shame the girl, Mary Grace's indignation grows. In the midst of Ruby's praise and claims of thankfulness about her own life, Mary Grace's rage reaches her breaking point. She becomes inhuman, an animal-throwing her book into Ruby's face, flying across the table to attack her, sinking her "claws" into her flesh, and eventually writhing on the floor as she is captured by the doctor and others in the waiting room. Mary Grace's deterioration into animalism would seem the greater of evils when compared to Ruby's sin of smug self-satisfaction. However, when Ruby has a momentary vision, as if she were "looking through the wrong end of a telescope" (CS, p. 499), she realizes that Mary Grace is indeed a force to be recognized: "There was no doubt in her mind that the girl did know her, knew her in some intense and personal way, beyond time and place and condition" (CS, p. 500). When Ruby asks her what she has to say, Mary Grace tells her to "Go back to hell where you came from, you old warthog" (CS, p. 500). Ruby's subconscious seems to recognize the truth of Mary Grace's words, and the polite and pleasant "shell" that distinguishes Ruby from the fallen characters around her deteriorates. She rebukes the assistance of the doctor in the waiting room, "growl[ing]" under her breath at his attempt at levity and to care for her medically 
(CS, p. 501). She and Claud return home to their farm, and though she attempt to verbally deny Mary Grace's label, her "denial has no force" (CS, p. 502) and her "ferocious concentration" does not change (CS, p. 503). The next day, her denial focuses on garnering sympathy from the black women who work on the farm. As she tells them of her experience, they offer sympathy and defense of her, but Ruby sees their words as hollow and informed by the system of manners and economic hierarchy, much as her own behavior was prior to her encounter with Mary Grace. As she peels back the layers of good behavior, her rage grows: "She knew how much Negro flattery was worth" (CS, p. 505). We find her, again, growling to herself as she makes her way toward the hog pen which will become, as the story suggests, the place of her ultimate revelation.

In the final moments of the story, $\mathrm{O}^{\prime}$ Connor allows Ruby Turpin to reach a place of being which must register as "ultimate good." She moves outside her own narrow experience, outside the limitations of her cultural and society and becomes capable of more than just her own spiritual awakening. Her vision in the hog parlor moves her to the realm that $\mathrm{O}^{\prime} \mathrm{Connor}$ would call the "reality of distance." Ruby feels the vision coming on, and indeed, it has been coming on since her entrance into the doctor's office. The feeling is less of anticipation and more of inescapable destiny, and she absorbs its slow unfolding as "abysmal life-giving knowledge" (CS, p. 508). She never sees herself deprived of the characteristics which she holds to be virtuous- "having a little of everything and the God-given wit to use it right" - but the beauty of her vision is that she sees "good" as well as evil as having been "burned away" (CS, p. 508).

Jack Dillard Ashley considers this and other "theophanies" in O'Connor's work, and seeks to underscore the value of the Old Testament concept of appearance, manifestation, and revelation. Ashley claims that the term goes beyond the idea of "epiphany", which is associated with New Testament notions of spiritual awakening, and claims that the concept of theophany is a more powerful way of understanding the moments in $\mathrm{O}^{\prime}$ Connor's fiction, as it is associated with "the macrocosm" in its focus on the concrete manifestations of God in the tangible world, and it arouses the emotions of "terror, awe, reverence and sorrow" instead of those associated with epiphany: "light, illumination, recognition, and elevation of reason" "The Very Heart of Mystery: Theophany in O'Connor's Stories", p. 103). About "Revelation", Ashley has this to say: "Apparently, suffering by theophany was worth it for Ruby Turpin, since ordinary phenomena of macrocosm are transformed into the sonorous ecstasy of luminous Theocosm" (Ashley 2006, p. 109). He quotes Revelation's last paragraph as proof:

At length she got down and turned off the faucet and made her slow way on the darkening path to the house. In the woods around her the invisible cricket choruses had struck up but what she heard were the voices of the souls climbing upward into the starry field and shouting hallelujah. (CS, p. 509)

This understanding of theophany serves to attest to the competitions among all forms of good and evil, where the battles are interesting, but the ultimate victory has already been secured. O'Connor makes her argument about theodicy in both of her novels and almost every story. She frames the battles of good and evil, but masks them as we try assigning them to simplistic categories. Good and evil are palpable, but they often appear in costumes that can be changed as the stage requires. Locating examples of clear evil and clear good is challenging, and for critics of her work even exasperating. O'Connor does not offer these challenges arbitrarily, in order to simply make her work obtuse. In her notes on craft as a guide to readers and writers, she explains: "From my own experience in trying to make stories 'work,' I have discovered that what is needed is an action that is totally unexpected, yet totally believable, and I have found that, for me, this is always an action which indicates that grace has been offered. And it is frequently an action in which the devil has been the unwilling instrument of grace" (MM, p. 118). She depicts the world she sees around her, one in which competitions between acts of good, competitions between acts of evil, and competitions between evil and good all end in the same place: in ultimate and Divine convergence. If we cannot name them and differentiate between them, it is because all these matters are in a state of flux; an awareness of that theological state of being should bring comfort as we move toward ultimate unity. 
Acknowledgments: The author of this article wishes to acknowledge the support of editor, Jill Graper-Hernandez for her patience and incredible inspiration.

Conflicts of Interest: The author declares no conflict of interest.

\section{References}

Ashley, Jack Dillard. 2006. The Very Heart of Mystery: Theophany in O'Connor's Stories. In Flannery O'Connor's Radical Reality. Edited by Jan Nordby and Karl-Heinz Westarp. Columbia: University of South Carolina Press. Coulthard, A. Ronald. 1987. 'A View of the Woods': A View of the Worst. Notes on Contemporary Fiction 17: 7-9.

Gentry, Marshall Bruce. 1986. The Demonic O'Connor: The Violent Bear it Away and the Lame Shall Enter First. In Flannery O'Connor's Religion of the Grotesque. Jackson: University Press of Mississippi.

McCarty, Doran. 1976. Teilhard de Chardin. Waco: World Books Publisher.

O'Connor, Flannery. 1962. Flannery O'Connor; Mystery and Manners. Occassional Prose Selected and Edited by Sally and Robert Fitzgerald; New York: Farrar, Straus, Giroux. [Referred to as MM in text].

O'Connor, Flannery. 1979. The Habit of Being: Letters of Flannery O'Connor. Edited by Sally Fitzgerald. New York: Farrar, Straus, Giroux, [Referred to as HB in text].

O'Connor, Flannery. 1987. Flannery O'Connor: The Complete Stories. New York: Farrar, Straus and Giroux. [Referred to as CS in text].

O'Connor, Flannery. 2009. Flannery O'Connor on the Catholic Novelist in the Protestant South. The Chesterton Review 15: 730-40. [CrossRef]

Savery, Louis, and Patricia Berne. 2015. Teilhard Chardin's Seven Stages of Suffering: A Spiritual Path for Transformation. Mahwah: Paulist Press.

(C) 2018 by the author. Licensee MDPI, Basel, Switzerland. This article is an open access article distributed under the terms and conditions of the Creative Commons Attribution (CC BY) license (http:/ / creativecommons.org/licenses/by/4.0/). 